\title{
AnReQuim: UM RECURSO DIGITAL PARA O ENSINO DE QUÍMICA
}

\author{
João Milani Júnior ${ }^{1}$ \\ José Wilson Pires Carvalho
}

\begin{abstract}
Resumo: Com a crescente presença no contexto social, os dispositivos móveis vêm sendo apontados como uma alternativa para uso em atividades de ensino. De modo que, o objetivo do presente trabalho foi construir um objeto digital de aprendizagem (ODA) do tipo aplicativo multiplataforma, com base em uma pesquisa junto a professores de química, para uso como recurso digital no ensino de conteúdos de equilíbrio químico. O tema 'equilíbrio químico' foi selecionado devido a reconhecida complexidade e importância para a compreensão de diversos assuntos da química. Assim, foi realizada uma pesquisa por meio da aplicaçáo de questionário, com professores de química do segundo ano do ensino médio de duas escolas públicas de Mato Grosso, com o intuito de obter os requisitos didáticopedagógicos e funcionais que o aplicativo precisava conter. Esta pesquisa apontou que os assuntos 'reaçôes químicas e balanceamento de equaçôes', 'constante de equilíbrios em termos de pressôes parciais' e 'influência do catalisador' foram os mais requisitados para estarem contidos no ODA. $\mathrm{Na}$ construção do aplicativo, foram utilizadas ferramentas livres/gratuitas, à fim de não gerar custos de licenciamento. O aplicativo construído foi denominado "AnReQuim". Esse aplicativo contém como atividades, trezentas e vinte e uma reaçôes diferentes, distribuídas em dez níveis distintos conforme a complexidade. Deste total, quarenta e oito reaçôes possuem animaçôes, construídas para a visualização da animação dos fenômeno a nível atômico/molecular. A utilização do aplicativo AnReQuim proporciona o acesso a animaçôes do fenômeno 'equilíbrio químico', podendo fomenter uma construção correta de significados, ora sendo o equilíbrio químico um fenômeno dinâmico, a utilizaçáo de representaçóes dinâmicas para os processos de ensino e aprendizagem apresenta destaque sobre os modelos estáticos. De modo análogo, o aluno pode perceber o comportamento e movimentos das partes envolvidas na reação, realizando a vinculação entre a variável teórica e sua representação. Portanto, o AnReQuim possui aspectos pedagógicos, técnicos e conteúdos planejados para atender necessidades dos processos de ensino e aprendizagem em química em sala de aula.
\end{abstract}

Palavras-chave: Química, equilíbrio químico, Objeto digital de Aprendizagem, Ensino.

1 Bacharel em Ciência da Computação, Mestre Ensino de Ciências e Matemática.

2 Licenciatura em Química, Metre e Doutor em Físico-Química, Professor do Programa de PósGraduaçáo em Ensino de Ciências e Matemática, Acadêmico. 


\title{
AnReQuim: A DIGITAL RESOURCE FOR THE TEACHING OF CHEMISTRY
}

\begin{abstract}
With the increasing presence in the social context, mobile devices have been pointed out as an alternative for use in teaching activities. So, the objective of this work was to construct a multiplatform application learning digital object (LDO), based on a research with chemistry teachers, for use as a digital resource in the teaching of chemical equilibrium contents. The theme 'chemical equilibrium' was selected because of the recognized complexity and importance of understanding various chemistry subjects. Thus, a questionnaire survey was carried out with chemistry teachers from the second year of high school in two public schools in Mato Grosso, in order to obtain the didactic-pedagogical and functional requirements that the application needed to contain. This research pointed out that the subjects 'chemical reactions and equation balancing', 'equilibrium constant in terms of partial pressures' and 'catalyst influence' were the most requested to be contained in the application. In the construction of the application, free / free tools were used, in order not to generate licensing costs. The built application was named "AnReQuim". This application contains in its activity, three hundred and twenty-one different reactions, distributed in ten different levels according to its complexity. Of this total, forty-eight reactions have animations, constructed to visualize the animation of the phenomena at the atomic / molecular level. The use of the AnReQuim application provides access to animations of the phenomenon 'chemical equilibrium', promoting a correct construction of meanings, or chemical equilibrium being a dynamic phenomenon, the use of dynamic representations for the teaching and learning process presents a highlight on the models static. In a similar way, the student can perceive the behavior and movements of the parties involved in the reaction, making the connection between the theoretical variable and its representation. Therefore, AnReQuim has pedagogical, technical and content aspects designed to meet the needs of the teaching and learning processes in chemistry and the classroom.
\end{abstract}

Keywords: Chemistry, Chemical equilibrium, Digital Learning Object, Teaching.

\section{Introduçáo}

Estudos têm discutido que o conhecimento em química é importante para a autonomia do sujeito, por contribuir para que possa construir suas próprias visóes de mundo, interpretação e compreensão da natureza, para o desenvolvimento de percepçôes que expliquem os fenômenos vivenciados no cotidiano. Soma-se também o fato de que o conhecimento pode proporcionar autonomia aos estudantes, permitindo-os posicionarem-se diante de questóes da sociedade tecnológica, envolvendo diferentes problemáticas (SANTOS; SCHNETZLER, 1996; MACENO; GUIMARÁES, 2013). Neste caminho, a construção e uso de objetos digitais de aprendizagem (ODA) podem ser importantes no ensino de química, podendo contribuir para uma melhor compreensão dos estudantes e contribuir com as atividades pedagógicas dos professores tornando-as mais estimulantes aos processos de ensino e aprendizagem.

Apesar da existência de objetos digitais de aprendizagem que podem ser utilizados nos processos de ensino e aprendizagem de ciências/química, é necessário que haja compatibilidade entre as demandas do professor e os recursos oferecidos. Para que ocorra esta proximidade, a construçáo destes objetos deve ocorrer apoiada 
nas necessidades oriundas da percepçáo de professores, de seu cotidiano em sala de aula (OLIVEIRA; SOUTO; CARVALHO, 2016; OLIVEIRA; MILANI JUNIOR; CARVALHO, 2020; OLIVEIRA; CARVALHO, 2020).

Com o intuito de fomentar os processos de ensino e aprendizagem de equilíbrio químico, o presente trabalho teve por objetivo construir um objeto digital de aprendizagem do tipo aplicativo multiplataforma, com base em uma pesquisa com professores de química sobre o uso de recurso digital e os assuntos associados ao conteúdo de equilíbrio químico que deveriam estarem contemplados no aplicativo. Com base nesta pesquisa, foi formulada a pergunta norteadora deste trabalho "É possível construir um objeto de aprendizagem (aplicativo) voltados ao ensino de química no segundo ano do Ensino Médio, seguindo uma demanda apontada por um grupo de professores de química de uma escola pública?”.

O tema "equilíbrio químico" foi selecionado por seu papel axial no ensino da química. Mendonça e Ferreira (2005) afirmam que a compreensão do equilíbrio químico é 'estrutural', de modo que outros conteúdos de química se desenvolvem fundamentados em seus conceitos, mas estudos apontam para a existência de dificuldades nos processos de ensino e aprendizagem desse conteúdo (FERREIRA e JUSTI, 2008; FABIÃO e DUARTE, 2005). Devido à complexidade e abstração 3 do tema, Raviolo e Garritz (2008, p. 23) apontam como estratégia válida, o uso de "analogias", contudo Montagna (2013, p. 8) afirma que existe "um halo nas tecnologias de ensino dedicadas a trabalhar num aspecto táo central do ensino de química que é o equilíbrio químico", afirmando ainda que, se tratando de um conceito fundamental, "não tem recebido a atenção esperada".

\section{Os objetos digitais de aprendizagem}

Estudos têm demonstrado uma tendência crescente no uso das Tecnologias da Informação e Comunicaçáo (TICs) na educação, como recursos de apoio aos processos de ensino e aprendizagem (GIORDAN; GÓIS, 2004; MACENO; GUIMARÃES, 2013; OLIVEIRA; CARVALHO; KAPITANGO-A-SAMBA, 2019; PASCOIN; CARVALHO; SOUTO, 2019; SILVA; SANTOS, 2017). Entre estas Tecnologias, estão os objetos digitais de aprendizagem (ODA). De acordo com Trindade (2012, p.1) " objeto de aprendizagem (OA) é qualquer entidade digital, que pode ser usada, reusada ou referenciada durante um processo de aprendizagem apoiado pela tecnologia”, ou seja, qualquer imagem, vídeo, áudio, animação, simulaçáo, hipertexto e software utilizado para fins de aprendizagem pode ser considerado um objeto digital de aprendizagem.

3 O termo abstração refere-se à natureza particulada e submicroscópica do fenômeno "equilíbrio químico", fato este que não propicia sua visualização, demandando a construção de um modelo mental do conceito teorizado.

4 Raviolo e Garritz (2008) definem "analogia" como um conjunto de relaçôes estabelecidas entre um dado objeto desconhecido (sobre o qual se deseja aprender), e seu análogo (objeto familiar ao aluno), sobre o qual detém-se conhecimento. 
As animações são recursos de apoio para a construção de conceitos. Tavares (2008, p.4) afirma que "a animação interativa utiliza um modelo aceito cientificamente para simular um evento específico." A simulação deste evento denota a característica de abstrair conceitos específicos, afirma Braga (2014, p.23) quando conceitua que "as animaçóes interativas podem se tornar recursos didáticos valiosos na compreensão de conceitos. Sendo assim, uma animação pode ser considerada como um OA", uma vez que "seu uso estimula processos cognitivos como percepção, memória, linguagem, pensamento e outros".

As simulaçôes são conceituadas por Braga (2014, p. 25) como "animaçôes que representam um modelo da natureza" e que por este fato "podem ser muito utilizadas como objetos de aprendizagem". Segundo Bassani (2006, p. 3) as simulações "permitem a apresentação de informações, a observação de fenômenos e a manipulação de hipóteses". Tavares $(2008$, p. 4) propóe seu uso em atividades experimentais, onde "podemos simultaneamente fazer animaçóes de ideias antagônicas, e analisar quais as implicaçóes de cada uma para o resultado final da simulação de um dado evento". Hipertextos são popularmente conhecidos como "páginas na Internet", caracterizados por suas ligaçôes (os links) para outros hipertextos. Podem ser categorizados como objetos de aprendizagem os que se destinam a apoiar os processos de ensino e aprendizagem, como cursos a distância e aulas virtuais (BRAGA 2014).

A utilização de recurso multimídia oportuniza a simulação de cenários e a modelizaçóes de exercícios e de teorias, dentro de uma sequência de conteúdos. A característica mais promissora de um recurso multimídia para o ensino é a capacidade de suportar o uso de animaçôes e visualizaçóes interativas (GARNETT; OLIVER, HACKLING, 1998; SILVA; SANTOS, 2017).

Aguiar e Flôres (2014) afirmam que é conveniente o uso de animaçóes para promover uma melhor compreensão e concepçáo de conceitos complexos por parte dos alunos, bem como, de simulaçóes que possibilitem o ajuste de parâmetros de modo que possam ser observadas no fenômeno simulado, as relaçôes de causa e efeito. Considerando o nível submicroscópico da química, é necessário observar que o entendimento e a compreensão por parte do aluno, baseiam-se muitas vezes no conceito teórico, uma vez que a escala dos eventos não favorece sua visualização em experimentos laboratoriais. Deste modo, a forma dinâmica e interativa dos recursos multimídia para a demonstração do conteúdo teorizado fomenta um entendimento correto e a correta construção de significados (GARNETT; OLIVER; HACKLING, 1998).

As animações são definidas por Giordan e Góis (2004) como um produto gerado por aplicativos de ediçáo gráfica, com a intenção de ressaltar alguma característica superficial, desconsiderando suas demais características como escalas de tempo e tamanho. Todavia, as simulaçóes são geradas com base em parâmetros estabelecidos de modo a satisfazer os comportamentos que descrevem o fenômeno simulado. Parâmetros como movimento e trajetória são componentes 
preponderantes para a concepção de um modelo físico correto (GARNETT; OLIVER; HACKLING, 1998).

A possibilidade de acesso a tecnologias móveis ocasiona novos métodos de comunicação, informação e interação social. Contudo, estas alteraçôes têm refletido na maneira de abordagem de conteúdos em ambiente escolar, uma vez que "tradicionalmente, a aprendizagem de informaçôes e conceitos era tarefa exclusiva da escola" (KENSKI, 2003, p. 25) e agora não mais. Com os adventos tecnológicos como a popularização dos smartphones, as tarefas de ensinar e aprender tornam-se outras formas e dimensóes, motivando os indivíduos a um "permanente estado de aprendizagem e de adaptação ao novo", onde o antes inatingível, encontra-se nas mãos e bolsos das pessoas (ESTEVARENGO, 2016).

\section{Características dos objetos digitais de aprendizagem}

Os objetos digitais de aprendizagem devem possuir características técnicas e pedagógicas específicas. As denominadas como características técnicas são aquelas com relação direta com as tecnologias empregadas em sua construção como: disponibilidade, acessibilidade, confiabilidade, portabilidade, facilidade de instalação, interoperabilidade, usabilidade, granularidade, agregação, durabilidade e reusabilidade. As características consideradas pedagógicas são aquelas ligadas diretamente ao desenvolvimento escolar como: interatividade, autonomia, cooperação, cognição e afetividade (Braga, 2014).

A interatividade de um ODA refere-se à capacidade de intervenção do aluno. É sem dúvida uma característica primordial em um objeto digital de aprendizagem e é impressa por meio das mídias utilizadas, em função destas, podendo ser mais ou menos interativo o objeto (BRAGA, 2014). A autonomia apoia a iniciativa e permite que decisóes sejam tomadas. É uma característica presente em objetos digitais de aprendizagem interativos. Caso haja cooperação, o objeto digital de aprendizagem deve permitir a execução da tarefa proposta de forma colaborativa. A cognição é um aspecto fundamental para que o ODA não falhe em sua missão. Seu conteúdo deve ser autoexplicativo, para que a interaçáo aconteça de maneira eficiente. A afetividade denota a capacidade de despertar o sentimento de motivação para a execução da atividade. A disponibilidade indica se o objeto possui acesso em qualquer tempo (ou em momentos específicos aliados a aspectos técnicos). A acessibilidade caracteriza os tipos de acesso que o objeto terá, se pode ser manipulado por idosos, crianças, deficientes ou se necessita de meio específico (tal como internet, cd's) ou equipamento (computador e tablet).

A confiabilidade apresenta-se sob a forma técnica e pedagógica. Sob a forma técnica, sua elaboração deve ser robusta de modo a não falhar em situação de uso. Sob a forma pedagógica, seu conteúdo deve remeter fielmente ao planejamento realizado para a execuçáo da atividade, de forma concisa e coerente. A portabilidade sinaliza se o objeto digital de aprendizagem oferece suporte à migraçáo para outros ambientes e/ou plataformas. A facilidade de instalação refere-se à instalação do objeto. A interoperabilidade refere-se à capacidade de integração do conteúdo do 
ODA com outros sistemas. Macêdo et al. (2007, p. 334) afirmam que "os OA possuem a interoperabilidade, ou seja, a capacidade de ser utilizado em qualquer plataforma de ensino em todo o mundo".

A usabilidade denota a facilidade de uso pelo público alvo. A ausência desta característica no objeto pode contribuir para o desencorajamento de seu uso. A granularidade representa um nível de detalhe, que permite ao objeto conter objetos internos, reusáveis e portáveis. A agregação determina se os ODA podem ser agrupados, de modo a compor uma série ou uma sequência. A durabilidade indica a estabilidade do conteúdo quanto à uma variação técnica do ambiente que o hospeda, como uma oscilação de comunicação com a internet. A reusabilidade consolidase como uma característica primordial, pois a informação contida no objeto pode e deverá ser revisitada quantas vezes for necessário. Aspectos econômicos podem ser observados, com a diminuição da aquisição de licenças e novos programas (MACÊDO et al., 2007).

No entanto, durante a elaboração de um ODA, é provável que alguma das características listadas acima náo seja contemplada, contudo "quanto mais características ele tiver, maior a sua capacidade de reutilização" (BRAGA, 2014, p. $35)$.

$\mathrm{Na}$ construção de aplicativos para dispositivos móveis, nota-se a existência de diversas opçôes, classificadas como "nativas" ou "híbridas". Lopes (2016, p.1) afirma que "as plataformas nativamente oferecem a possibilidade de criar aplicativos" por meio do emprego de kits de desenvolvimento próprios conhecidos como $\mathrm{SDK}^{5}$. Utilizando tais kits torna-se possível, por meio da linguagem de programaçáo suportada pela plataforma, construir e distribuir aplicaçóes, contudo, cada plataforma possui sua combinaçáo específica de linguagem e API ${ }^{6}$ (LOPES, 2016). As particularidades de cada plataforma tornam onerosos os esforços para a construção de um aplicativo que atenda de forma comum a diversas plataformas, englobando desde a reprogramação à aquisição de licenças (CERQUEIRA; BITTENCOURT, 2013).

De forma a simplificar a construção de aplicativos para dispositivos móveis, têm surgido tecnologias com foco em aplicaçóes híbridas, como o Apache Cordova, "inicialmente chamado PhoneGap, que consiste em uma plataforma para a geração de aplicaçôes HTML5 em diversos sistemas operacionais móveis (Android, iOS, Windows Phone, etc.)" (CÁSSIO, 2015, p. 7). Esta variedade de plataformas móveis

5 Software development kit. Kit de desenvolvimento de software que contém o compilador e ferramentas de desenvolvimento relacionadas. (HORSTMANN, 2009, p.688).

6 Segundo (HORSTMANN, 2009, p.75), “A API (Application Programming Interface) é a interface de programaçáo de aplicativo". 
soma-se ao fato de que o aplicativo é codificado utilizando-se apenas um conjunto padronizado de tecnologias, o $\mathrm{HTML}^{7}$, o $\mathrm{CSS}^{8}$ e o JavaScript ${ }^{9}$ (LOPES, 2016).

\section{Metodologia}

Como forma de conhecer as demandas referentes à construção de um aplicativo para uso como recurso digital no ensino de conteúdos de equilíbrio químico, foi elaborado um questionário diagnóstico com seis questóes fechadas, de múltipla escolha e aplicado a professores, com opçóes que permitiam apontamentos em mais de um assunto do conteúdo de equilíbrio químico. Desta forma pôde-se conhecer os conteúdos considerados complexos sob o ponto de vista do processo de ensino e aprendizagem.

A aplicaçáo deste questionário aconteceu no mês de janeiro de 2017, direcionado a professores de química que lecionam em turmas do segundo ano do ensino médio, devido ao fato do tópico equilíbrio químico ser abordado na ementa, de duas escolas públicas estaduais situadas em Barra do Bugres e Arenápolis, Estado de Mato Grosso. Nestas duas localidades encontramos apenas cinco professores de química que lecionassem a disciplina para o segundo ano do ensino médio. Convidamos todos para participar da pesquisa e destes apenas um optou por não responder ao questionário. Assim, nomeamos os sujeitos da pesquisa neste trabalho com a letra "P" seguida de um número.

Figura 1 - Etapas da execução deste trabalho

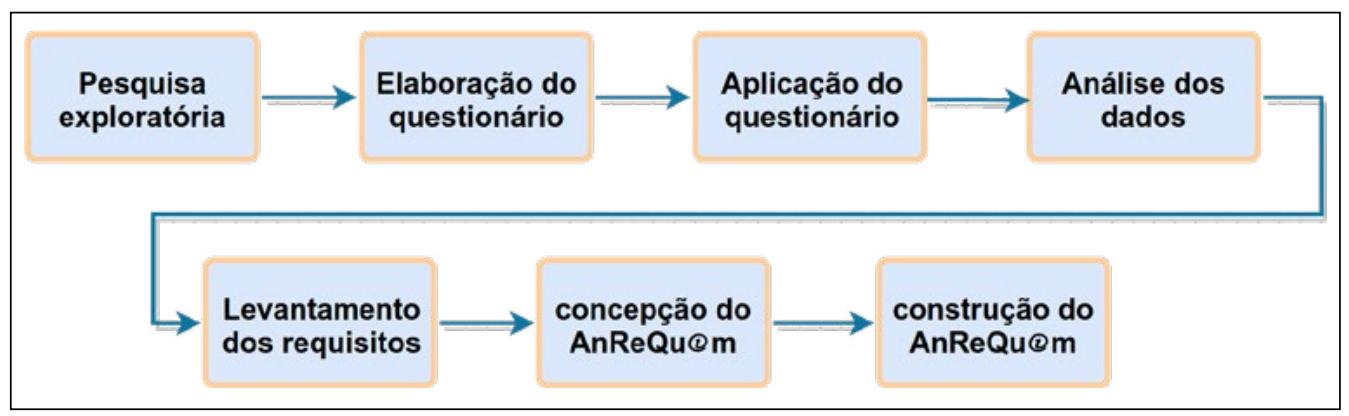

Fonte: compilação dos autores.

7 HTML é o acrônimo para HyperText Markup Language, linguagem de marcação de hipertexto. O HTML tem função estrutural na composição de uma aplicação, possibilitando a organização de seu conteúdo (FERREIRA; EIS, 2011).

8 O termo CSS abrevia Cascading Style Sheets, folhas de estilo em cascata, utilizadas para definir os aspectos visuais dos elementos HTML (SHAW, 2015).

9 JavaScript é uma linguagem de programação responsável por aplicar comportamento a elementos HTML, proporcionando interatividade aos objetos da aplicação (MOZILLA, 2017). 
Os apontamentos expressos por meio do questionário diagnóstico, ilustrado no quadro 1 , forneceram as demandas dos professores participantes sobre o tema. $\mathrm{O}$ agrupamento de tais apontamentos permitiu identificar alguns anseios e padróes indispensáveis para a construção de um ODA para o contexto da sala de aula na percepção dos professores. A leitura destes dados levou aos requisitos para o aplicativo, AnReQuim, uma vez que os professores devem participar do processo de concepção do aplicativo, de forma a produzir um ODA que possibilite o reuso (BRAGA; PIMENTEL; DOTTA, 2013).

\section{Quadro 1 - Questionário diagnóstico}

1. Com base na sua experiência em sala de aula, com quais dos conteúdos listados abaixo alunos apresentam maiores dificuldades de compreensáo e aprendizagem? Selecione quantos julgar necessário.

( ) Reações químicas e balanceamento de equaçóes

( ) Conceito de reações químicas reversíveis;

( ) Conceito de equilíbrio químico;

( ) Equilíbrios químico homogêneos e heterogêneos;

( ) Grau de equilíbrio em uma reação;

( ) Constante de equilíbrio;

( ) Constante de equilíbrios em termos

de pressôes parciais;

( ) Deslocamento do equilíbrio

(princípio de Lê Chatelier);

() Influência do catalisador

( ) Outros, quais?

2. Ao abordar diferentes tópicos de Equilíbrio Químico, quais conteúdos dos listados abaixo você considera mais complexos/difíceis de serem trabalhados/ensinados?

( ) Reações químicas e balanceamento de equaçóes;

( ) Conceito de reaçóes químicas reversíveis;

( ) Conceito de equilíbrio químico;

( ) Equilíbrios químico homogêneos e heterogêneos;

( ) Grau de equilíbrio em uma reação;

( ) Constante de equilíbrio;

( ) Constante de equilíbrios em termos de pressóes parciais;

( ) Deslocamento do equilíbrio (princípio de Lê Chatelier);

( ) Influência do catalisador;

( ) Outros. quais?
3. Quais fatores você considera que poderiam contribuir para os processos de ensino e aprendizagem dos tópicos do conteúdo de equilíbrio químico citados anteriormente (questôes 1 e 2)?

\begin{tabular}{|l|l|}
\hline $\begin{array}{l}\text { ( ) Recursos didático- } \\
\text { pedagógicos }\end{array}$ & $\begin{array}{l}\text { ( ) Mais interesse e } \\
\text { motivaçáo do aluno }\end{array}$ \\
\hline $\begin{array}{l}\text { ( ) Melhores metodologias } \\
\text { de ensino }\end{array}$ & $\begin{array}{l}\text { ( ) Mais recursos } \\
\text { tecnológicos }\end{array}$ \\
\hline ( ) Outros. Quais? & \\
\hline
\end{tabular}

4. Com base em sua experiência docente, como você percebe o uso de recursos educacionais digitais em sala de aula?

\begin{tabular}{|l|l|}
\hline $\begin{array}{l}\text { ( ) Acho interessante e } \\
\text { gostaria de aplicar }\end{array}$ & $\begin{array}{l}\text { ( ) Acho interessante, } \\
\text { mas não aplicaria }\end{array}$ \\
\hline $\begin{array}{l}\text { ( ) Não tenho opinião } \\
\text { formada }\end{array}$ & $\begin{array}{l}\text { ( ) Não acho } \\
\text { interessante }\end{array}$ \\
\hline ( ) Outros. Quais? &
\end{tabular}

5. Você conhece ou já utilizou algum recurso educacional digital no ensino de tópicos equilíbrio químico?

() Sim. Qual?

( ) Náo.

6. Supondo que você esteja planejando construir um recurso digital (aplicativo) para auxiliar os processos de ensino e aprendizagem de tópicos do conteúdo de equilíbrio químico. Quais dos aspectos abaixo você consideraria imprescindível? Selecione quantos julgar necessário.

( ) Uma introdução do conteúdo: história, aplicaçóes, exemplos e curiosidades.

( ) Abordagem do conteúdo por meio de diferentes representaçōes: audiovisual, atividades interativas, simulaçóes, exercícios, conceitos, etc.

( ) Abordagem do conteúdo na forma de revisão: conceitos, simulaçóes, imagens, vídeos, exemplos exercícios interativos.

( ) Outros. Quais? Abordagem do conteúdo: conceitos, simulaçôes, imagens, vídeos, exemplos exercícios interativos, exemplos de onde seriam utilizados.

Fonte: compilação dos autores. 
De maneira a viabilizar o uso do aplicativo AnReQuim em um maior número de dispositivos, observando os requisitos levantados junto aos professores, o mesmo foi construído como um 'aplicativo híbrido', utilizando o Apache Cordova como framework $^{10}$. Esta ferramenta possui licença gratuita e código aberto, possibilitando seu reuso e a interoperabilidade. Segundo Bassani (2006, p.2) "um dos aspectos que chama a atenção no desenvolvimento de software educativo é a carência de uma metodologia específica para projetá-los e desenvolvê-los", uma vez que o "software educativo busca atender e promover a aprendizagem, a demanda cognitiva para a aquisição do conhecimento e a construção de relaçôes e conceitos". Este trabalho não desconsidera a existência de diversas metodologias, largamente utilizadas nos processos de desenvolvimento de software, todavia, as especificidades das demandas dos softwares educacionais necessitam ser observados e atendidos.

Os resultados da idealização e construção do ODA foram expostas por uma narrativa do processo e das características, uma vez que a narrativa aparenta ser o melhor instrumento no processo de descrição de uma experiência, sendo utilizada inclusive na tecnologia da informaçáo, fornecendo uma maneira de organizar as formas complexas da experiência de modo que possa ser descrita (SCHOSTAK, 1996; DE OLIVEIRA, 2008; GOMES, 2003).

\section{Resultados e discussóes}

\section{Apontamentos e percepçóes dos professores de química sobre o ensino e aprendizagem de conteúdos de equilíbrio químico e a construçáo do aplicativo AnReQuim}

Por meio da aplicação do questionário (Quadro 1) foi obtida a percepção dos professores sobre assuntos que compóem o conteúdo de equilíbrio químico, de forma que nortearam a construção do objeto digital de aprendizagem, AnReQuim. Onde a primeira questão (Q1) do questionário (Quadro 1) foi a seguinte: 'Com base na sua experiência em sala de aula, com quais dos conteúdos listados abaixo os alunos apresentam maiores dificuldades de compreensão e aprendizagem? Selecione quantos julgar necessário'. Esta questão possibilitou aos professores apontarem quais conteúdos os alunos apresentam maiores dificuldades nos processos de ensino e aprendizagem com base na experiência da docência em aula (figura 2a).

Tomando por parâmetro as alternativas que alcançaram mais de $10 \%$ de apontamento pelos professores, observa-se que os assuntos 'Constante de equilíbrios em termos de pressões parciais', 'Reaçóes químicas e balanceamento de equaçôes', 'Grau de equilíbrio em uma reação' e 'Influência do catalisador' foram os que receberam mais apontamentos, como sendo assuntos que os alunos demonstram ter maior dificuldade de aprendizagem. Esses resultados se mostram consistentes

10 Um framework é uma biblioteca de recursos, que podem compartilhar diversos tipos de funçôes. (BEZERRA; SCHIMIGUEL, 2016, p. 7). 
com a complexidade que o conteúdo equilíbrio químico representa (RAVIOLO; GARRITZ, 2008; FABIÁO; DUARTE, 2005), de modo que não houve consenso ou tendência que apontasse para uma única opçáo específica e todos os assuntos receberam apontamentos (figura 2a).

Por se tratar de um tema axial no qual se apoiam importantes conceitos de química, torna-se compreensível que todas as opçóes de resposta (figura 2a) recebessem a atenção dos participantes da pesquisa. Uma vez que, a compreensão e entendimento do equilíbrio químico tornam-se basilar para temas como: 'conceito de reaçóes químicas reversíveis', 'conceito de equilíbrio químico', 'equilíbrio químico homogêneo e heterogêneo', 'constante de equilíbrio' e 'deslocamento do equilíbrio (princípio de Lê Chatelier), também apontados como assuntos de maior dificuldade de aprendizagem, em consonância com estudos que apontam para a existência de dificuldades nos processos de ensino e aprendizagem do equilíbrio químico (FERREIRA; JUSTI, 2008; FABIÁO; DUARTE, 2005).

Figura 2 - Apontamentos dos professores sobre as dificuldades nos processos de ensino e aprendizagem de conteúdos de equilíbrio químico.

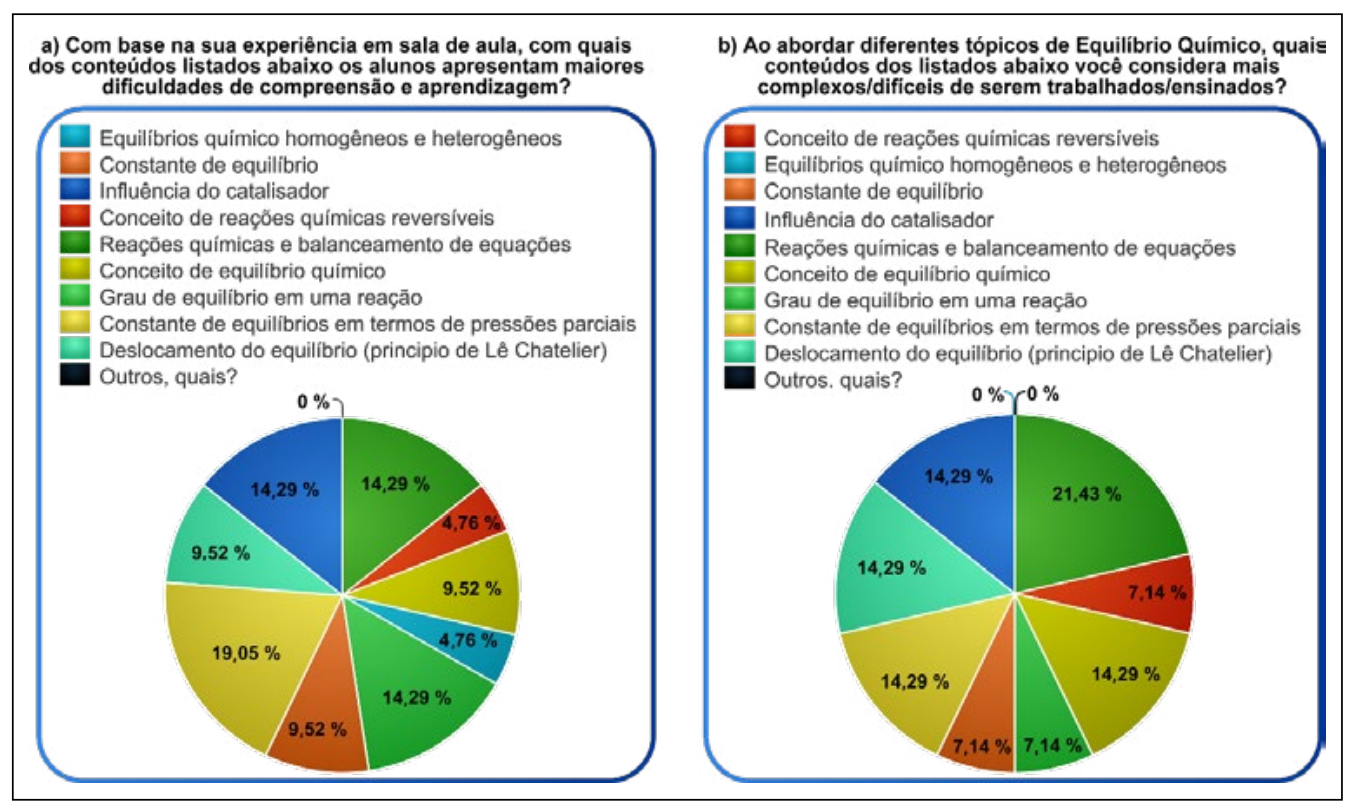

Fonte: compilação dos autores.

De modo a conhecer as dificuldades encontradas pelos professores, nos processos de ensino e aprendizagem dos assuntos relacionados ao conteúdo de equilíbrio químico, a segunda pergunta do questionário (Quadro 1) foi: Ao abordar diferentes tópicos de Equilíbrio Quimico, quais conteúdos dos listados abaixo você considera mais complexos/dificeis de serem trabalhados/ensinados?. Como pode ser observado na figura $2 \mathrm{~b}$ todas as alternativas foram assinaladas ao menos uma vez, fato este que pode sugerir a existência de dificuldades por parte do professor, que 
pode contribuir para que o processo de ensino náo ocorra como planejado. Além do mais, os assuntos que mais receberam apontamentos foram 'Reaçôes químicas e balanceamento de equaçôes', 'Conceito de equilíbrio químico', 'Constante de equilíbrios em termos de pressóes parciais', 'Deslocamento do equilíbrio (princípio de Lê Chatelier)' e 'Influência do catalisador' (figura 2b). Esses resultados percentuais mostram que os conteúdos listados são considerados complexos para serem ensinados. Esta complexidade no processo de ensino pode estar relacionada com a dificuldade de abstraçáo dos conceitos expostos (ROCHA, 2012), bem como um eventual desinteresse por parte dos estudantes (MESSEDER NETO, 2016). A complexidade do tema 'equilíbrio químico' é associada a natureza particulada dos fenômenos e uma das dificuldades da aprendizagem de química encontra-se na compreensão e interpretação do complexo mundo das transformaçôes químicas (MENESES, 2015), mundo este dividido em três níveis: 'submicroscópico', 'macroscópico' e 'simbólico'. O nível submicroscópico representa uma representação do comportamento particulado dos elementos da reação, o que deve ser abstraído devido à sua natureza não observável "a olho nu". O nível macroscópico de uma reação pode ser definido por seus aspectos visíveis como mudança de fase, variação de temperatura, coloração e desprendimento de gás/vapor, por exemplo. O nível simbólico se refere à representação escrita da reação (GARNETT; OLIVER; HACKLING, 1998). A dificuldade na compreensão dos diferentes níveis de representação do fenômeno químico e a percepçáo da relação entre estes representa, segundo Meneses (2015, p.48), um dos fatores complicadores dos processos de ensino e aprendizagem de química.

Desta forma, pode-se observar que existe uma relação entre o que os professores consideram "difícil de aprender" e o que consideram ser "difícil de ensinar" quando analisados os dados apresentados na figura 2. Esta similaridade de resultados entende-se como uma demanda por um recurso que fomente os processos de ensino e aprendizagem destes assuntos, uma vez que, o uso da inovaçáo pode fomentar a prática docente, transformando suas práticas e a construçáo do conhecimento entre os estudantes (BASTOS, 2005; GIORDAN; GÓIS, 2004).

Assim, tornam-se embasadores na construção do aplicativo AnReQuim os temas 'Reações químicas e balanceamento de equações', 'Constante de equilíbrios em termos de pressóes parciais' e 'Influência do catalisador' devido os apontamentos realizados pelos professores participantes da pesquisa (figura 2). Considerando que, a utilização de um ODA, provavelmente, trará contribuiçôes para professores e estudantes, uma vez que o emprego de analogias proporciona 'opçôes diferentes' para construção dos conceitos teóricos apresentados. Segundo Giordan (2005, p. 292) "a tradução entre representações químicas pode envolver não apenas a recuperação de conhecimento conceitual, mas também a criação de imagens mentais".

Nesse sentido, na resposta do questionário (quadro 1) um dos professores optou por expressar sua opiniáo sob forma literal, conforme exposta no excerto abaixo: 
Devido à complexidade do equilíbrio químico, o aluno tem muita dificuldade de interpretar o rendimento e extensão de uma reaçáo, compreender aspectos qualitativos, não tem compreensão do porquê de aprender equilíbrio químico, reação química, reversibilidade das reações e também as deficiências conceituais. (PROFESSOR P1 $1^{11}$, QUESTIONÁRIO APLICADO EM 23/01/2017).

A opiniáo desse professor corrobora com o disposto na literatura, uma vez que "as dificuldades associadas ao ensino e à aprendizagem de química perpassam, geralmente, o aspecto abstrato dessa ciência" conforme Raviolo e Garritz (2008, p.13) e Ferreira e Justi (2008, p.32) que afirmam, os alunos "não têm compreensão do porquê de aprender equilíbrio químico (...)". Nesse caso, o professor expóe uma das dificuldades que, provavelmente, decorrente do ensino de ciências, de modo que o entendimento e a compreensão dos fenômenos são dados através da leitura pessoal sobre o fenômeno, como discutido por Pozo e Crespo (2009), em que o uso apropriado de representaçóes pode auxiliar o processo de construção de significado dos temas citados pelo professor.

Diante do exposto acima, buscou-se saber por intermédio da questão 3 (Quadro 1) 'quais fatores os professores consideram que poderiam motivar os processos de ensino e aprendizagem dos tópicos do conteúdo de equilíbrio químico citados anteriormente?'. Os resultados para esta questão podem ser observados na figura 3 a.

Nesses resultados, percebido que parte dos professores consideram como fatores importantes 'Mais interesse e motivação do aluno (28,57\%)' e "Melhores metodologias de ensino (28,57\%)" (figura 3a). Esta percepção condiz com o descrito por Pozo e Crespo (2009) ao retratarem uma 'crise' na educação científica, de forma que os alunos, aparentemente, aprendem cada vez menos e com menos interesse, adotando condutas inadequadas ou incompatíveis com os fins da ciência. Esta problemática provoca uma desvalorização do saber com consequências para a vida do indivíduo, uma vez que, a química se faz presente nos eventos da vida cotidiana. Assim sendo, seu aprendizado deve ocorrer de forma construtiva, com a busca de significados e corretas interpretaçóes, o que invariavelmente demanda interesse e motivação por parte dos alunos (BRASIL, 2016; MESSEDER NETO, 2016; OLIVEIRA; CARVALHO; KAPITANGO-A-SAMBA, 2019; PASCOIN; CARVALHO; SOUTO, 2019; POZO; CRESPO, 2009; OLIVEIRA; CARVALHO, 2020).

11 A natureza dos questionamentos inferidos por meio do questionário aplicado buscava satisfazer nossa busca por parâmetros concretos para a consolidaçáo da pesquisa. Contudo, o Professor P1 nos surpreende com sua generosidade e presteza, colaborando ricamente com suas opinióes às margens do questionário. 
Figura 3 - Percepção dos professores sobre recursos educacionais e o uso de tecnologias digitais no ensino de química.

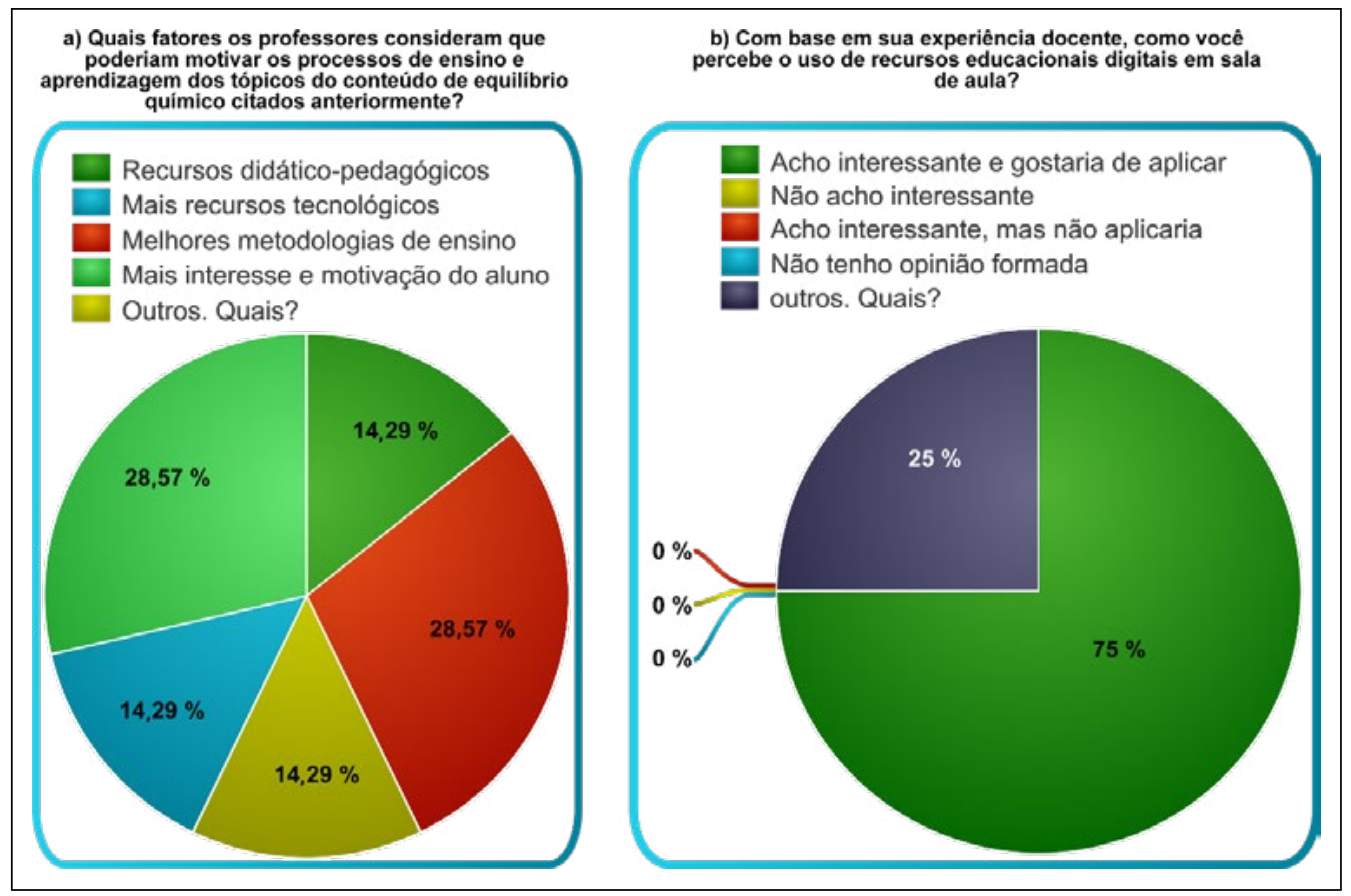

Fonte: compilação dos autores.

Com relaçáo, a carência por melhores metodologias de ensino apontadas por parte dos professores denota uma oportunidade de implantação de algum recurso que possa contribuir no processo de mediaçáo do ensino em sala de aula, como um ODA. Também são apontados pelos professores, as opçóes 'mais recursos tecnológicos (14,29\%)' e 'recursos didático-pedagógicos (14,29\%)', fatos que apontam para uma propensão ao aceite de um objeto digital de aprendizagem (como retorno ao apelo 'mais recursos tecnológicos') e sua utilizaçáo em um contexto apropriado como recurso potencializador dos processos de ensino e aprendizagem de equilíbrio químico ('recursos didático-pedagógicos', figura 3a). A utilização de um recurso multimídia pode oportunizar a modelizaçáo de teorias por meio de suas características, dentre as quais a "interatividade", viabilizando a visualização de fenômenos, fomentando um entendimento correto e com construçôes significativas (GARNETT; OLIVER; HACKLING, 1998; SILVA; SANTOS, 2017).

Em tal contexto, um dos professores selecionou a opção ‘Outros. Quais?’ da questão 3 do questionário (Quadro 1), e expressou à abordando a contextualização e a interdisciplinaridade.

"Interdisciplinaridade e a contextualização, recursos para ampliar possibilidades de interação entre disciplinas, mas infelizmente há um distanciamento" (PROFESSOR P1, QUESTIONÁRIO APLICADO EM 23/01/2017). 
A observação do professor P1 pode ser compreendido no exposto por Rua e Souza (2010, p. 96) onde afirmam que "o processo ensino-aprendizagem dinâmico, interdisciplinar e contextualizado pode ser um modo de o professor despertar nos alunos a consciência da importância da química". De forma dinâmica, a química é experimentada na vida cotidiana, o que viabiliza a contextualizaçáo dos conteúdos, de modo que a construçáo do conhecimento ocorre através da leitura pessoal do fenômeno estudado, tornando conveniente a inclusão de elementos familiares ao aluno nos processos de ensino e aprendizagem (BRASIL, 2016; POZO e CRESPO, 2009).

Ademais, a questáo 4 do questionário (Quadro 1): Com base em sua experiência docente, como você percebe o uso de recursos educacionais digitais em sala de aula?. Os resultados são mostrados na figura $3 \mathrm{~b}$, onde $75 \%$ dos professores responderam que 'acham interessante e gostariam de aplicar' e $25 \%$ assinalaram a opção outros (figura 3b). Este interesse de uso de recursos digitais em sala de aula demonstrados pelos professores pode refletir a necessidade que os professores possuem de aprendizagem e adaptaçáo ao novo, onde o bom uso da tecnologia pode levar à alteraçóes de comportamento de professores e alunos (KENSKI, 2003). Contudo, um professor assinalando a opção 'Outros. Quais?' fez a seguinte afirmação: “Acho interessante, mas não basta ter tecnologia e sim metodologia" (PROFESSOR P3 ${ }^{12}$, QUESTIONÁRIO APLICADO EM 23/01/2017). De fato, o uso de metodologias e recursos diferenciados para o ensino de química deve ser fomentado, uma vez que seus tópicos abordam fenômenos de natureza dinâmica, com diversas variáveis e observáveis por diversos escopos, demandando uma explanação por vezes imaginária, de um fenômeno que não se pode ver. Devido à aspectos, de natureza particulada e representação submicroscópica, torna-se necessário o uso de recursos que alcançam o que o livro didático não alcança, com animaçôes, recursos interativos, e todos os artifícios que o professor puder dispor para que desperte no aluno a curiosidade e a vontade de descobrir uma ciência que até entáo ainda é apresentada de modo estático nos livros didáticos.

De forma ao conhecer a experiência dos professores com recurso digitais no ensino de química, a quinta questão foi elaborada como segue: Você conhece ou já utilizou algum recurso educacional digital no ensino de tópicos equilíbrio químico?'. Como observado na figura $4 \mathrm{a}$, a totalidade dos professores assinalaram que náo conhecem ou que ainda não utilizaram quaisquer ODA para o ensino de equilíbrio químico, fato este que soma ao exposto por Montagna (2013, p. 8) ao afirmar que existe "um halo nas tecnologias de ensino dedicadas a trabalhar num aspecto tão central do ensino de química que é o equilíbrio químico". Contudo, existe a propensão ao uso já constatada, refletindo o interesse dos professores e o estado de adaptação ao novo descrito por Kenski (2003).

12 Apenas o professor P3 assinalou a opção "outros. Quais?” da questão 4 do questionário. Por este motivo sua afirmação está transcrita integralmente no texto. 
Por outro lado, visando conhecer as expectativas e anseios dos professores a respeito de um recurso digital do tipo aplicativo, a questáo 6 foi assim redigida: 'Supondo que você esteja planejando construir um recurso digital (aplicativo) para auxiliar os processos de ensino e aprendizagem de tópicos do conteúdo de equilíbrio quimico. Quais dos aspectos abaixo você consideraria imprescindivel? Selecione quantos julgar necessário' (Quadro 1). Esta questão teve por finalidade levantar os anseios dos professores com relação à construção de um ODA que lhes auxilie como um recurso válido e têm seus resultados expostos na figura $4 \mathrm{~b}$.

Figura 4 - Percepção dos professores sobre recursos digitais utilizáveis em situaçóes de ensino conteúdos de equilíbrio químico.

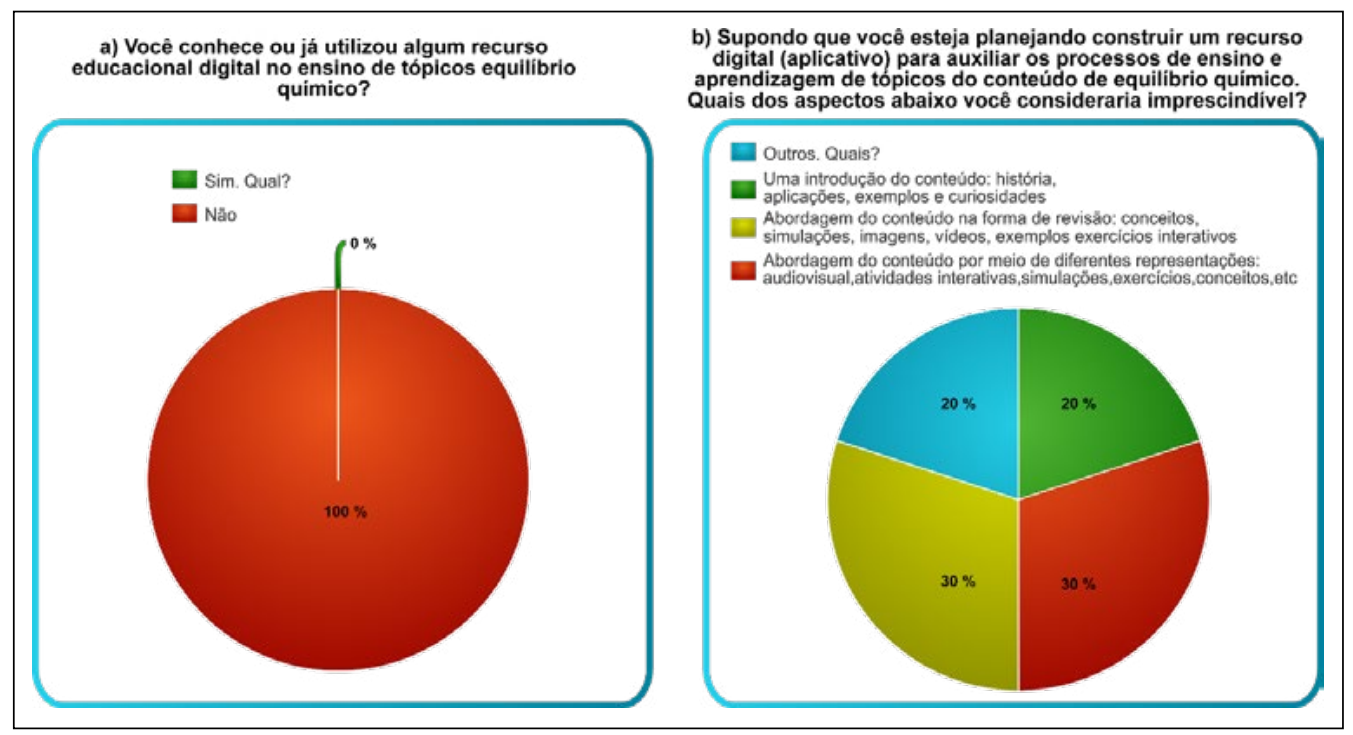

Fonte: compilação dos autores.

Sugerindo um anseio por uma abordagem baseada em conteúdos bem delimitados, a maioria dos professores assinalaram por 'abordagens de conteúdo (30\%)', provavelmente, cientes das possibilidades que podem ser alcançadas com a utilizaçáo de um aplicativo que seja capaz de promover uma 'reflexáo' diferente sobre o conteúdo abordado em sala de aula, que possa colaborar com a construçáo do saber científico presente no assunto abordado. A abordagem de conteúdos tornase essencial, contudo, existe a necessidade de diversificar a reflexão realizada sobre os conteúdos, de modo que a construçáo dos conceitos represente o dinamismo dos fenômenos, náo apenas sua representaçáo algébrica. Partindo desta necessidade, surge a demanda por ODA que proporcionem ao estudante uma abstração visual dos conceitos, de forma dinâmica e não apenas estática como exposto em livros didáticos, como afirmam Raviolo e Garritz (2008, p.23), "poucas analogias mostram o dinamismo da reação química com a ruptura de ligaçóes e redistribuição dos átomos nas moléculas", devido à complexidade do fenômeno e sua forma dinâmica. 
Assim, com base no exposto pelos resultados do questionário (figuras 2, 3 e 4) foi possível avaliar a demanda e qual a real necessidade da construção de um objeto digital de aprendizagem do tipo aplicativo estabelecendo os requisitos que nortearam a construção do aplicativo AnReQuim. De modo que, com base nos resultados, os conteúdos que o aplicativo deveria conter são: 'Reaçóes químicas e balanceamento de equaçóes', 'Constante de equilíbrios em termos de pressóes parciais' e 'Influência do catalisador'. Deve possuir uma estruturação de modo que propicie 'mais interesse e motivação do aluno', o que deve ocorrer durante o uso, uma vez que a propensão ao novo é uma característica dos recursos digitais. A facilidade de utilização deve ser observada, uma vez que os professores têm interesse em utilizar o aplicativo, mas náo possuem experiência ainda com a utilização de recursos digitais nos processos de ensino e aprendizagem.

\section{O aplicativo AnReQuim: concepçáo e construçáo}

Deste modo, analisando os resultados obtidos com o questionário e apontamentos dos professores, foram definidos os requisitos didático-pedagógicos e funcionais a serem implementados na construçáo do aplicativo AnReQuim. Os requisitos 'não funcionais' observados foram definidos com base no referencial teórico específico sobre as características dos objetos digitais de aprendizagem, onde são apontados os aspectos 'desejáveis' que cada objeto digital de aprendizagem deve conter (BRAGA, 2014; TAROUCO, 2004). Além disso, AnReQuim foi construído para funcionar em diferentes equipamentos (smartphone, computador, tablet, entre outros) e diferentes sistemas operacionais sem a necessidade de conexão com a internet. O nome "AnReQuim", decorre da junção dos termos "Análise de Reações Químicas", de forma "lúdica".

De posse dos requisitos, foi iniciada a tarefa de construção do objeto digital de aprendizagem AnReQuim. De início, o intuito foi de construir uma simulação, pois a literatura defende-as como um valoroso recurso de ensino, viabilizando a experimentação sob vários aspectos do objeto simulado (GIORDAN; GÓIS, 2004; GARNETT; OLIVER; HACKLING, 1998; SILVA; SANTOS, 2017; OLIVEIRA; CARVALHO, 2020). Assim, foi iniciado a construção de um modelo computacional que simula o equilíbrio químico das reações de formação da amônia $\mathrm{N}_{2(\mathrm{~g})}+\mathrm{H}_{2(\mathrm{~g})} \otimes \mathrm{NH}_{3(\mathrm{~g})}$. Como a reação ocorre entre dois gases, concebemos um baláo "virtual" com tampa, como visto na figura $5 \mathrm{a}$, de forma a imprimir realidade no objeto e dinamismo. Ponderando, os três níveis de representação da reação química (GARNETT; OLIVER; HACKLING, 1998), compreende-se que o simbólico já está contemplado na forma escrita da reação, o macroscópico necessitaria de uma outra abordagem e em alguns casos náo ocorreria mudança visível. Assim, foi construído sua representação em nível submicroscópico/molecular, de modo que o professor e o aluno podem observar o fenômeno do equilíbrio e a dinâmica dos movimentos das moléculas durante simulação da reação. Após a definição do recipiente (figura 5a) e o nível de representação da reação, foram criadas esferas que representam os átomos das moléculas da reação, colorindo-as conforme a 
representaçáo do elemento na tabela periódica, imprimindo assim uniformidade ao AnReQuim. Dessa forma, manter os átomos "presos" dentro do baláo, uma vez que se tratam de dois gases, foi gerada uma "máscara de colisão", composta por um arranjo de figuras geométricas que formam uma "parede" sob a forma do contorno externo do baláo (figura 5b). A configuração desta "parede" é realizada por meio de um arquivo $\mathrm{JSON}^{13}$, onde pode-se alterar suas propriedades em qualquer tempo, como visto na figura $5 \mathrm{~b}$.

Figura 5 a) Baláo "virtual” com tampa construído para o aplicativo AnReQuim e b) máscara de colisão das moléculas com a parede do frasco virtual construído para o aplicativo AnReQuim.

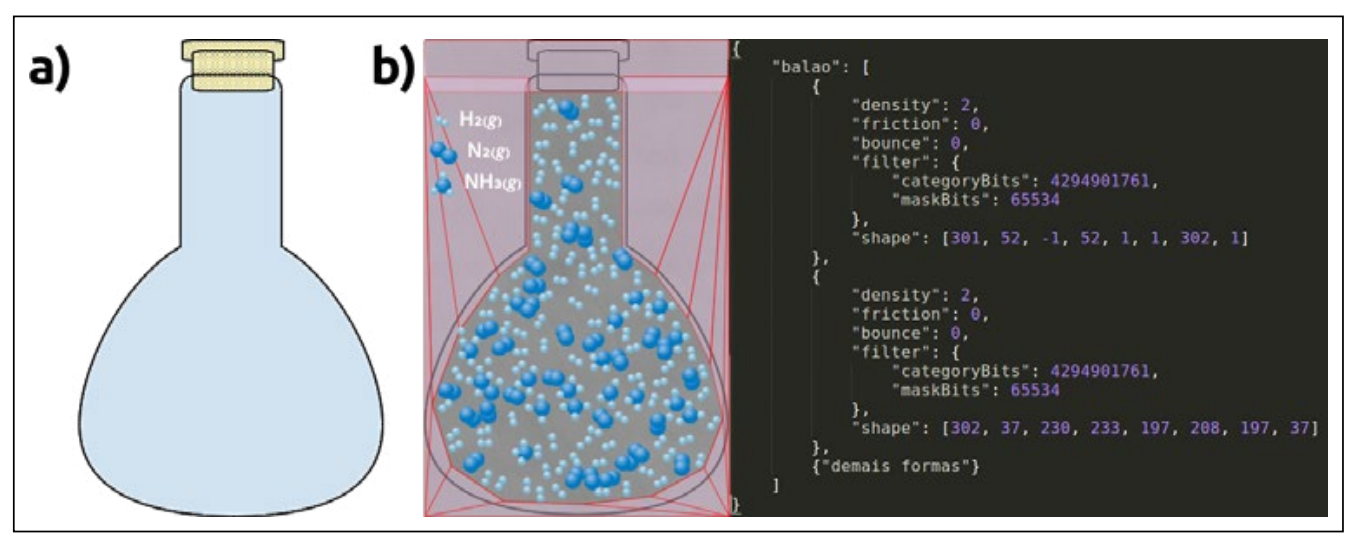

Fonte: compilação dos autores.

Neste ponto da construção do AnReQuim foi utilizado um modelo físico de modo a configurar movimento e comportamento das moléculas, bem como, a gravidade, as colisôes das partículas, suas associaçóes e dissociaçóes. Entretanto, as simulaçóes de teste apresentaram um consumo elevado de recursos computacionais, devido à grande quantidade de elementos envolvidos, o que inviabilizaria sua execução em dispositivos moveis modestos. Com o intuito de produzir uma aplicação funcional e com garantia de funcionamento em todos os dispositivos disponíveis, mesmo aqueles mais modestos, optou-se por produzir animaçôes ao invés de simulaçóes. Assim, as reaçóes selecionadas foram simuladas e estas simulaçóes foram salvas em vídeo, de modo que, o aplicativo mostrou bom desempenho em smartphones modestos como um dispositivo com 1 gigabyte de memória RAM $^{14} \mathrm{e}$ um processador de 1.3 giga-hertz (Figura 6).

13 JSON (JavaScript Object Notation) é um formato leve de troca de dados. Fonte: https://www. json.org.

14 RAM -Random Access Memory 
De forma a construir as animaçóes, foi realizado uma seleção de reaçôes de diferentes graus de complexidade e em número suficiente para que náo ocorressem repetiçôes, o que poderia tornar o aplicativo desinteressante ao aluno. De forma basilar foram utilizados dois livros como referências, "Handbook of inorganic chemicals" de Patnaik (2003) e "The condensed chemical dictionary" de Olsen (1919). De modo a prover informaçóes sobre a reação, o produto da reação, ou seus reagentes, foram também utilizadas referências oriundas de fichas de manuseio, de fabricantes e distribuidores de produtos químicos, de modo que são disponibilizadas 321 reaçôes no aplicativo. Dentre estas, são reproduzidas $48 \mathrm{em}$ animações, como a mostrada nas figuras $5 \mathrm{~b}$ e $6 \mathrm{~b}-\mathrm{d}$.

Como pode ser observado na figura 6 , também foram construídas animações que representam reaçôes em que mostram condiçôes de equilíbrio em sistemas homogêneos (figuras 6b, 6d) e o equilíbrio heterogêneo (figuras 6a e 6c).

Figura 6 - Animaçóes de reaçóes construídas e disponibilizadas no AnReQuim.

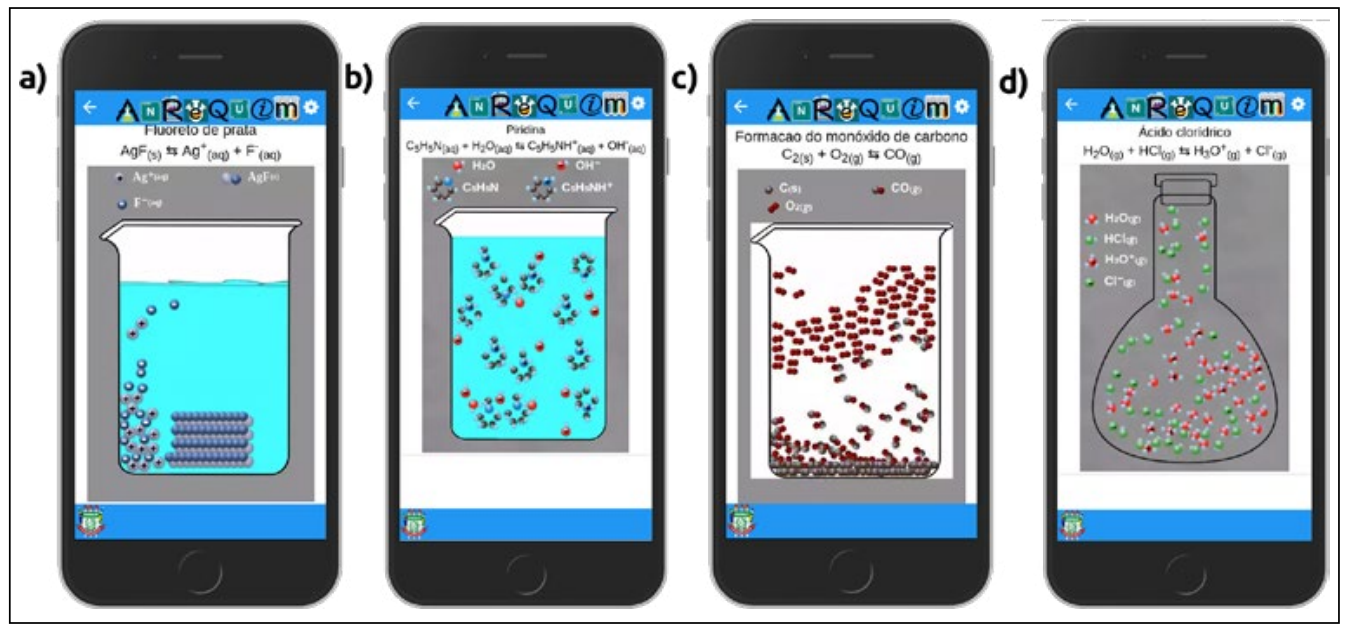

Fonte: compilação dos autores.

Os elementos dispostos na animação são de vital importância para a conceituação do fenômeno simulado, resultando em uma situação de importante 'valor didático' para a elaboração do significado (GIORDAN; GÓIS, 2004). A coerência de formas, proporções, cores e o ângulo das ligações propóem confiabilidade no modelo, com sua correta representação do conceito, uma vez que as reaçóes ocorrem em nível atômico/molecular, o uso de recursos multimídia propicia a oportunidade de acesso a representaçóes apropriadas do fenômeno estudado (GARNETT; OLIVER; HACKLING, 1998). As animaçóes propiciam uma visualização agradável das reaçóes, tornando mais estimulante e com potencial para 'prender' a atenção do aluno, quando comparada a modelos estáticos (GIORDAN, 2005), devido a natureza dinâmica do equilíbrio químico os modelos estáticos são deficientes. Percebe-se que essas animaçôes dispostas na figura 6 possibilitam a abordagem de uma variedade de assuntos que podem ser a formaçáo de íons, troca 
de cargas, mudanças de fase e as propriedades associadas a reaçóes em recipientes fechados envolvendo gases.

O AnReQuim também oferece atividade onde o aluno deve ajustar corretamente os coeficientes estequiométricos da reação, de forma que ao final a reação esteja balanceada, como mostrado na figura 10a. Além disso, as trezentas e vinte e uma reaçóes são dispostas em dez níveis de complexidade, organizadas e distribuídas de forma a estimular a execução da atividade. Os coeficientes estequiométricos que o aplicativo informa inicialmente ao aluno são redefinidos a cada execução de modo aleatório, considerando a lei das proporçôes definidas com coeficientes inteiros (ATKINS, 2001; FELTRE, 2004), evitando assim que o aluno "decore" as respostas, que são calculadas no momento que o aluno interage com o aplicativo, ou clique, no botão "responder". Ao concluir o balanceamento das reaçóes, o aluno recebe um feedback do aplicativo, revelando informaçóes de seu progresso, como o "percentual de acertos" o que vem a conferir uma característica desafiadora, podendo despertar o interesse do aluno. Este percentual de acertos é incrementado somente quando o aluno responde corretamente a atividade, os erros não são computados. Ainda neste diálogo do feedback, o aluno tem as opçóes "repetir" caso queira tentar novamente a reação que tenha errado o balanceamento, mas com outros valores de coeficientes estequiométricos iniciais. Usando a opção "próxima", o aluno pode em qualquer momento, acertando ou não o balanceamento da reação, acessar a próxima reação. Desta forma, o aplicativo permite que a execução da atividade seja interessante para o aluno, não 'segurando' o aluno em sua dificuldade, permitindo-o escolher outras opçóes para poder prosseguir na atividade e revisitar novamente em outro momento aquela reação que seja de interesse (figura 7).

Figura 7 - Telas do aplicativo AnReQuim, balanceamento de equaçóes e mostrando o desempenho do aluno no desenvolvimento da atividade.

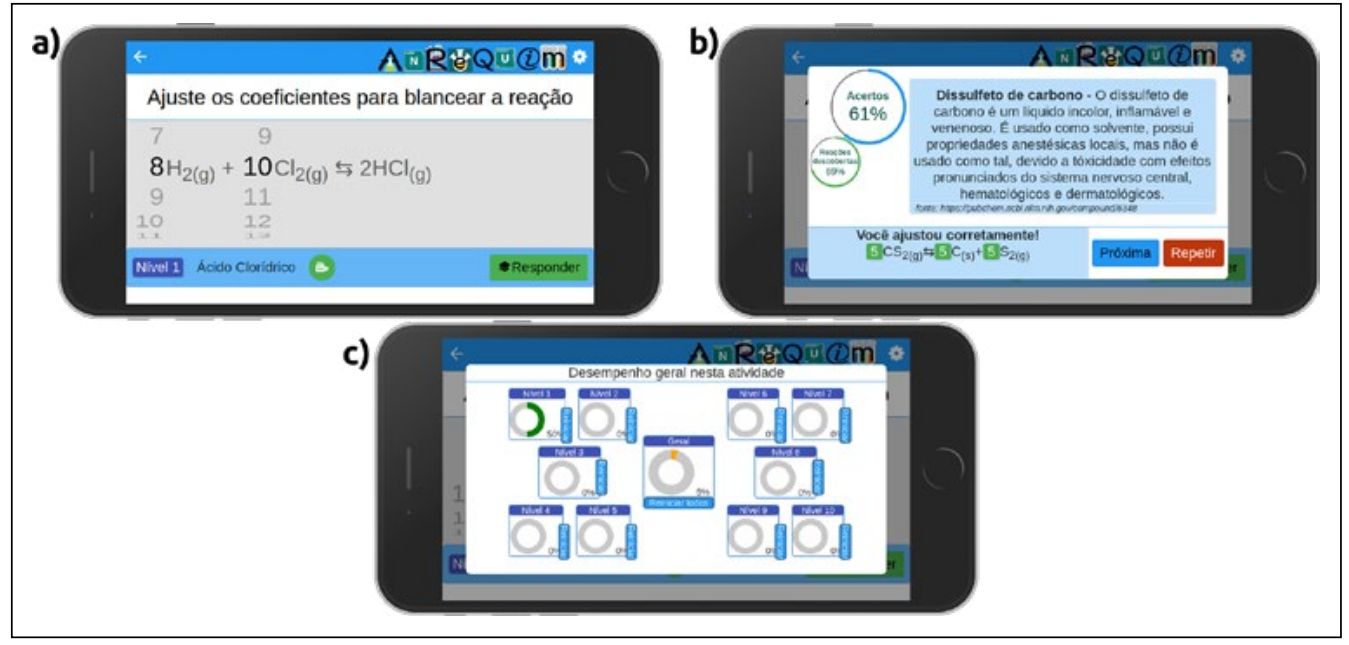

Fonte: compilação dos autores. 
A janela de feedback dispóe também de informaçóes como o percentual de "reaçôes descobertas", caracterizado pelo número de reaçôes já respondida dentre o universo das trezentas e vinte e uma que o aluno pode acessar, independentemente de ter acertado ou não. Caso o aluno realize o balanceamento da reação corretamente, ele visualiza os coeficientes estequiométricos da reaçáo na cor verde e conhecerá uma curiosidade sobre um ou alguns dos compostos que participam da reação (figura $7 \mathrm{~b}$ ). Esta curiosidade tem por finalidade chamar a atenção do aluno para algo que em muitos casos estar presente no nosso cotidiano e por vezes náo sabemos do que se trata, ou para que serve ou de onde vem, nutrindo assim uma ideia de recompensa e fomentando a participação do indivíduo nos processos de ensino e aprendizagem (POZO; CRESPO, 2009). A utilizaçáo desta 'curiosidade' sobre a reação agrega um elemento lúdico aos processos de ensino e aprendizagem, contribuindo positivamente para a aprendizagem de conceitos como o equilíbrio químico (MESSENDER NETO, 2016). Desta forma, o aluno, provavelmente, se interessará pela atividade a fim de conhecer mais sobre as reaçôes que até então, ocasionalmente, não significará mais que letras em uma expressão em seu caderno.

Como forma de prover uma 'visualizaçáo' do fenômeno do equilíbrio químico, quarenta e oito reaçôes possuem animaçôes, que ficam disponíveis ao aluno por meio de um botáo verde com o símbolo de uma câmera de vídeo que aparece ao lado do nome do produto da reação (figura $7 \mathrm{a}$ ). As animaçóes estáo representadas de forma análoga, com seus tamanhos, movimentos e comportamentos acessíveis aos olhos humanos, tornando visualizável um fenômeno que até então necessitava de uma expressão algébrica para ser expresso, corretamente compreendido e significativamente interpretado (GARNETT; OLIVER; HACKLING, 1998). Ao visualizar a reação escrita e sua animação, o aluno tem a oportunidade de visualizar a dinâmica que ocorre com as moléculas envolvidas na reação, de modo que as diferentes representaçóes de um fenômeno impliquem na probabilidade de vinculação entre a variável teórica e sua representação, expressa de forma imagética (GIORDAN; GÓIS, 2004).

A tela de atividades dispóe ainda de um botáo no canto inferior esquerdo, onde pode-se ver o nível em que a atividade está sendo executada. Ao acionar este botão, uma janela exibe os contadores de desempenho obtidos na atividade em cada um dos dez níveis e em toda a atividade também, de maneira que o aluno pode selecionar um novo nível para a atividade ou simplesmente limpar os contadores e começar novamente do primeiro nível (figura 7c). Esta função denota uma autonomia disponível ao aluno ou professor, que pode curiosamente pretender conhecer as reaçôes do "nível 9", mesmo que ainda não tenha realizado a atividade em níveis anteriores. Esta autonomia permite que o aluno tenha plena liberdade e "se arrisque um pouco", fato que amplia e potencializa as possibilidades da aprendizagem, uma vez que o indivíduo deve se sentir "provocado" e estimulado a participar do processo, criando assim uma atmosfera lúdica e de aprendizado consciente (OLIVEIRA; CARVALHO, 2020; MESSEDER NETO, 2016; POZO; CRESPO, 2009). 
Durante a concepção e construção do AnReQuim, manteve-se uma constante atenção para que o aplicativo contivesse as características desejáveis que são esperadas em um ODA, sendo: "interatividade, autonomia, cooperação, cognição, afetividade, disponibilidade, acessibilidade, confiabilidade, portabilidade, facilidade de instalação, interoperabilidade, usabilidade, granularidade, agregação, durabilidade e reusabilidade" (BRAGA, 2014; TAROUCO, 2004). Para a representação das reaçóes neste primeiro momento, foram utilizadas animaçôes por critérios técnicos. As animações diferem das simulações, pois estas não suportam a manipulação de parâmetros ao longo de sua execução deste modo, parâmetros variação de pressão, temperatura ou adição dinâmica de reagentes somente seriam possíveis por meio da construção de simulaçóes.

Ao final do processo de construção do aplicativo AnReQuim, é possível observar que este atende positivamente à maioria dos aspectos desejáveis que um ODA deve possuir. Como a interatividade: o aplicativo foi construído com o uso de mídias interativas, como os controles de interface da atividade, vídeo e som. Autonomia: consequência da interatividade está presente na tomada de decisóes nas tarefas do aplicativo. Ao realizar uma atividade, o aluno conta com total liberdade para explorar novos níveis ou "repetir" a atividade com a última reação. São exemplos de autonomia impressos no AnReQuim.

Cognição: as informaçóes contidas no aplicativo são simples e de fácil entendimento, uma vez que as animações favorecem a visualização das reaçóes, fornecendo uma invariável abstração dos conceitos. Afetividade: a trama musical do aplicativo propositalmente instiga uma animosidade durante sua utilização, bem como as animações, com seus movimentos, formas e cores, atraem a atenção dos alunos para a visualização do fenômeno. Assim, como a curiosidade sobre a reação, a qual o aluno tem acesso apenas quando realiza corretamente o balanceamento, instiga o aluno a conhecer mais sobre as reações, despertando seu empenho e curiosidade (figura 5).

Disponibilidade: o AnReQuim foi concebido e construído para estar continuamente disponível, de modo que não dependesse de peculiaridades como "acesso à internet" e "disponibilidade de computadores". Optou-se por disponibilizar todo o conteúdo do aplicativo de forma única, ou seja, após a instalação já se encontra para pleno uso, sem a necessidade de downloads adicionais. Soma-se o fato de que, geralmente, os computadores alocados nas escolas estáo disponíveis apenas nos horários de aula, diferente do dispositivo móvel pessoal, o qual o aluno possui acesso em todo o tempo, na escola ou em casa.

Granularidade, Agregação, Interoperabilidade e portabilidade: o AnReQuim possui conteúdo granular, uma vez que coleciona seus objetos digitais de aprendizagem sob a forma de aplicaçáo, podendo ter seu conteúdo portado e "interoperado" para outras plataformas. Usabilidade, facilidade de instalação e acessibilidade: a facilidade de uso foi pautada como um dos requisitos da construção do aplicativo, uma vez que, qualquer complexidade em sua operaçáo dentro do 
contexto proposto, inviabilizaria seu uso. A instalação do aplicativo ocorre de modo simples, através de um único arquivo.

Confiabilidade, durabilidade e reusabilidade: o AnReQuim foi construído com o uso de tecnologias modernas e consolidadas, de forma a não falhar, o que the imprime confiabilidade técnica. As animaçôes e atividades foram revisadas como forma de garantir sua confiabilidade pedagógica. A durabilidade também é uma característica do AnReQuim. Este é durável por conta de sua plataforma móvel de operação (smartphoneltablet). Ao ser executado em um dispositivo móvel, o AnReQuim tem sua durabilidade mensurada estendida, pois os dispositivos móveis possuem baterias, que favorecem uma atividade "fora de sala", ou a continuidade das atividades em casos de "queda de energia". O reuso do aplicativo é potencializado por sua operação em dispositivos pessoais, uma vez que o aluno pode acessar o conteúdo do aplicativo em qualquer tempo e em qualquer lugar e quantas vezes desejar.

Dentre as características apresentadas por Braga (2014) e Tarouco (2004), apenas a cooperação ainda não está contemplada, uma vez que um dos requisitos do aplicativo é que funcionasse offline, ou seja, sem a necessidade de conexões externas, não havendo assim a cooperação online.

\section{Consideraçóes finais}

Com base no exposto, é notável que existe a demanda por algum recurso que auxilie os professores de química nos processos de ensino e aprendizagem dos conteúdos de equilíbrio químico. De fato, que este não é de fácil compreensão e desempenha um papel basilar para a concepção de outros tópicos do currículo de química. Para tal, deve este recurso ser algo atual, usual, atraente e cotidiano, que apresente aspectos de afetividade, usabilidade e dinamismo. Um ODA do tipo aplicativo para dispositivos móveis representa uma opção com grande chance de sucesso, uma vez que os dispositivos móveis estão cada vez mais presentes no cotidiano social e disponíveis para uso de forma quase que espontânea.

A utilização do AnReQuim pode proporcionar o acesso a representaçóes animadas do fenômeno 'equilíbrio químico', fomentando a correta construção de significados. Em sendo o equilíbrio químico um fenômeno dinâmico, a utilizaçáo de representaçóes dinâmicas para os processos de ensino e aprendizagem apresenta destaque sobre os modelos estáticos, de modo que o aluno perceba, de forma análoga, o comportamento e movimentos das partes envolvidas na reaçáo, oportunizando a vinculação entre a variável teórica e sua representação.

A construção do AnReQuim obedeceu com rigor critérios predispostos por uma demanda específica, que foi de um grupo de professores. Salientando critérios básicos, como a capacidade de operar offline, uma vez que a realidade das escolas ainda náo condiz com a velocidade dos avanços tecnológicos. Provavelmente, um aplicativo que dependa de conectividade com a internet produza um fator 
excludente, que poderia efetivamente dificultar o uso como didático nos processos de ensino e aprendizagem.

O AnReQuim pode funcionar em diversos tipos de aparelhos, como computadores, tablet's e smartphones, assim como em plataformas distintas, como Android, IOS, WindowsPhone, Firefox OS, BlackBerry, Web OS e Tizen e Fire OS. Este fato pode promover o uso do aplicativo na maioria massiva de equipamentos, abrangendo assim uma vasta gama de dispositivos, favorecendo seu uso em atividades coletivas em sala de sala ou fora dela.

A facilidade de utilização é uma característica almejada pelo AnReQuim, uma vez que seu público alvo náo dispóe de intimidade com os recursos digitais. Tornouse necessário construir um aplicativo intuitivo e de simples operação, de modo a produzir um recurso de auxílio válida para uso em sala de aula.

Todas as tecnologias envolvidas na construçâo do aplicativo AnReQuim são livres e gratuitas uma vez que diferente disso, seria gerado um custo de licenciamento, o que poderia inviabilizar sua construção e uso em diferentes cenários. $\mathrm{O}$ uso de ferramentas livres e gratuitas (de código aberto) favoreceu não somente sua concepção e construção, mas também favorecerá a manutenção do aplicativo, uma vez que pode ser distribuído, compartilhado e colaborado por outras pessoas, melhorando e expandindo as funcionalidades e potencialidades de seu uso no ensino.

Por fim, pode-se observar que é possível a construçáo de aplicativos com base em apontamentos de professores buscando atender demandas especificas dos processos de ensino e aprendizagem de conteúdos de Química é possível. Entretanto, os aspectos técnicos, funcionais e pedagógicos são fundamentos indispensáveis nessa empreitada e devem ser sempre observados, sem esquecer as especificidades de cada conteúdo e área do conhecimento.

\section{Referências}

Aguiar, E. V. B., \& Flôres, M. L. P. (2014). Objetos de aprendizagem: conceitos básicos. TAROUCO, Liane Margarida Rockenbach; COSTA, Valéria Machado da; ÁVILA, Barbara Gorziza et al. Objetos de aprendizagem: teoria e prática. Porto Alegre: Evangraf.

Aprendizagem para M-learning. In Florianópolis: SUCESU-Congresso Nacional de Tecnologia da Informação e Comunicação.

Atkins, P., Jones, L. (2001). Princípios de Química: Questionando a Vida Moderna e o Meio Ambiente. Bookman Editora.

Bassani, P. S., Passerino, L. M., Pasqualotti, P. R., \& Ritzel, M. I. (2006). Em busca de uma proposta metodológica para o desenvolvimento de software educativo colaborativo. Renote, 4(1).

Bezerra, P. T., \& Schimiguel, J. (2016). Desenvolvimento de Aplicações Mobile CrossPlatform Utilizando Phonegap. Observatorio de La economía latinoamericana. 
Braga, J. (2014). Objetos de Aprendizagem Volume 1: introdução e fundamentos. Santo André: Editora da UFABC.

Braga, J. C.; Pimentel, E.; Dotta, S. (2013). Processos e Metodologias para a Construção de Objetos de Aprendizagem. In: Objetos de aprendizagem: introdução e fundamentos. v. 1. 2013.

Cássio, E. (2015). Jogos em HTML5: Explore o mobile e física. São Paulo. Casa do Código.

Cerqueira, Douglas \& Bittencourt, Roberto. (2013). Comparação e Avaliação de Frameworks Mobile Multiplataforma. Universidade Estadual de Feira de Santana, Bahia, Brasil.

Estevarengo, L. F. (2016). Desenvolvendo jogos mobile com HTML5: Usando Phaser, Intel XDK e Cordova/PhoneGap. Novatec.

Fabião, L. S., \& Duarte, M. D. C. (2005). Dificuldades de produção e exploração de analogias: um estudo no tema equilíbrio químico com alunos/futuros professores de ciências. Revista Electrónica de Enseñanza de las Ciencias, 4(1), 1-17.

Feltre, R. (2004). Química. vol 2. São Paulo. Moderna.

Ferreira, E., \& Eis, D. (2011). HTML5: Curso W3C Escritório Brasil. São Paulo.

Ferreira, P. F. M., \& Justi, R. D. S. (2008). Modelagem e o "fazer ciência”. Química nova na escola, 28, 32-36.

Garnett, P., Oliver, R., \& Hackling, M. (1998). Designing interactive multimedia materials to support concept development in beginning chemistry classes. In Global Education on the Net: Proceedings of the Sixth International Conference on Computers in Education, Beijing/ Heidelberg: China Higher Education Press/Springer Verlag (Vol. 1, p. 297-304).

Giordan, M. (2005). O computador na educação em ciências: breve revisão crítica acerca de algumas formas de utilização. Ciência \& Educação, 11(2), 279-304.

Giordan, M., \& Góis, J. (2004). Telemática educacional e ensino de química: consideraçóes em torno do desenvolvimento de um construtor de objetos moleculares. RELATEC.

Kenski, V. M. (2003). Tecnologias e ensino presencial e a distância. Papirus Editora.

Lopes, S. (2016). Aplicaçóes mobile híbridas com Cordova e PhoneGap. Editora Casa do Código.

Macêdo, L. N. de, Macêdo, A. A. M., \& de Castro Filho, J. A. (2007). Avaliação de um objeto de aprendizagem com base nas teorias cognitivas. In Anais do Workshop de Informática na Escola (Vol. 1, No. 1). 
Maceno, N. G., \& Guimarães, O. M. (2013). A inovação na área de Educação Química. Química Nova na escola, 35(1), 48-56.

Mendonça, P. C., Justi, R. S., \& Ferreira, P. F. (2005). Analogias usadas no ensino de equilíbrio químico: compreensóes dos alunos e papel na aprendizagem. Enseñanza de las Ciencias, (Extra), 1-4.

Messeder Neto, H. S. (2016). O Lúdico no Ensino de Química na Perspectiva HistóricoCultural. Além do Espetáculo, Além da Aparência. Curitiba: Prismas.

Montagna, E., Moulatlet, A. C. B., Torres, B. B., \& Marson, G. A. (2012). Análise de aplicativos educacionais sobre equilíbrio químico. Anais do Encontro Nacional de Pesquisa em Educação em Ciências (ENPEC). Campinas.

Mozilla developer network. (2017). O que é o JavaScript. Recuperado em 10 julho, 2017, de https://developer.mozilla.org/pt-PT/docs/Web/JavaScript/O_que_é_o_JavaScript.

Oliveira, F. C. de, Souto, D. L. P., \& Carvalho, J. W. P. (2016). Seleção e análise de aplicativos com potencial para o ensino de química orgânica. Revista Tecnologias na Educação, v. 17.

Oliveira, F. C.; Carvalho, J. W. P. (2020). QuiLegAl application as a teaching resource from the perception of undergraduate Chemistry students. Actio: Docência em Ciências, $3,1-25$.

Oliveira, F. C.; Milani Junior, J.; Carvalho, J. W. P. (2020). Uso de aplicativos no ensino de química orgânica na percepção de discentes. Educação e Cultura Contemporânea, 17, 86-103.

Oliveira, M. E. R. S.N.; Carvalho, J. W. P., Kapitango-a-Samba, K.K. (2019).Objetos Digitais de Aprendizagem como Recurso Mediador do Ensino de Química. Revista Cocar, $13(27)$.

Olsen, J. C. (1919). The condensed chemical dictionary. Nova York, Press of J. J. Little \& Ives Co.

Pascoin, A. F., Carvalho, J. W. P.; Souto, D. L. P. (2019). Ensino de química orgânica com o uso dos objetos de aprendizagem atomlig e simulador construtor de moléculas. Revista Signos, 40(2).

Patnaik, P. (2003). Handbook of inorganic chemicals. New York: McGraw-Hill.

Pozo, J. I., \& Crespo, M. Á. G. (2009). A aprendizagem e o ensino de ciências: do conhecimento cotidiano ao conhecimento científico. Porto Alegre: Artmed, 5.

Raviolo, A., \& Garritz, A. (2008). Analogias no ensino do equilíbrio químico. Química Nova na Escola, 27(1), 13-25. 
Rua, E. R., \& Souza, P. S. A. (2010). Educação Ambiental em uma abordagem interdisciplinar e contextualizada por meio das disciplinas Química e Estudos Regionais. Química nova na escola, 32(2).

Santos, W. D., \& Schnetzler, R. P. (1996). Funçáo social: o que significa ensino de química para formar o cidadão. Química Nova na Escola, 4(4), 28-34.

Schostak, J. (1995). Narrative as a vehicle for research. Retrieved October, 4, 2002.

Shaw, peter. (2015). CSS3 Succinctly. Syncfusion. Morrisville, NC, EUA.

SILVA, Rosa Eulália da; SANTOS, Elizabeth dos. (2017). Recursos didáticos no ensino de ciências: a utilização de multimidias. Revista Areté - Revista Amazônica de Ensino de Ciências, 2 (3) 166-173.

Tarouco, L. M. R., Costa, V. M. D., Avila, B. G., Bez, M. R., \& Santos, E. F. D. (2014). Objetos de Aprendizagem: teoria e prática.

Tarouco, L. M., Fabre, M. C. J. M., Grando, A. R., \& Konrath, M. L. (2004). Objetos de Tavares, R. (2008). Aprendizagem significativa e o ensino de ciências. Ciências \& cognição, 13(1).

Trindade, A. G.; Braga, j. C.; Ponchio, R. A. (2012). Guia de Recomendação para o uso de objetos de aprendizagem na educação infantil: uma abordagem em softwares livres, In IX Congresso Brasileiro de Ensino Superior a Distância, Recife, PE. 